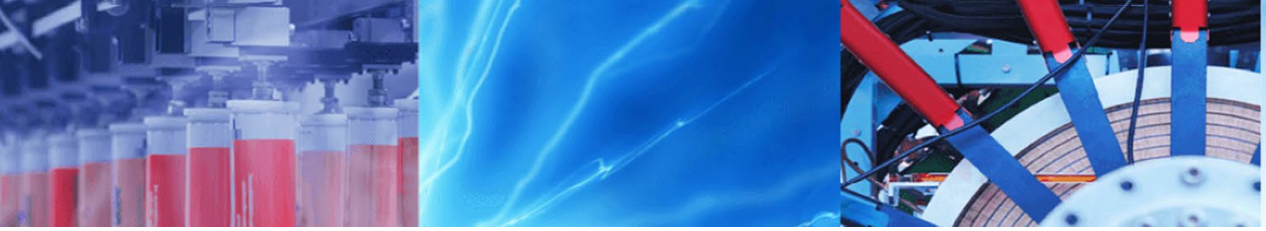

Research Article

\title{
Callus mediated biosynthesis and antibacterial activities of zinc oxide nanoparticles from Viola canescens: an important Himalayan medicinal herb
}

\author{
Arun Kumar Khajuria ${ }^{1,2} \cdot$ N. S. Bisht ${ }^{1} \cdot$ R. K. Manhas ${ }^{2} \cdot$ Goutam Kumar $^{3}$
}

(c) Springer Nature Switzerland AG 2019

\begin{abstract}
The plant mediated synthesis of metallic nanoparticles is preferred over chemical and physical methods owing to their easy synthesis, simplicity, eco-friendliness, stability and developed as lucrative field of green nanotechnology. Use of calli in place of other plant organ avoids the mass collection of plant from their wild habitat and offers the synthesis of nanoparticles for all those plants which are critically endangered or are not available throughout the year. In the present study, an alternative and novel protocol has been developed for the biosynthesis of Zinc Oxide nanoparticles (ZnO NPs) using in vitro culture technique of plant tissue culture as a basic platform for the plant material. Thus the present work aimed to synthesized ZnO NPs using the calli of Viola canescens (Banafsha) and study anti-microbial activity of synthesized nanoparticles. The calli were generated from the leaf and petiole explants, using the auxin (2,4-D and NAA) and cytokinin (Kn). Interaction of callus extract with Zinc nitrate hexahydarate extract for the bio-reduction of Zinc nitrate hexahydarate to its nanoparticles showed potency of calli to reduce Zinc nitrate to its nanosizes. The confirmation for the synthesis of the nanoparticles was done by UV-visible analysis followed by characterization of synthesized nanoparticles with XRD, FTIR and SEM techniques. X-ray diffraction analysis showed that nanoparticles exhibited the crystalline nature with wurtzite hexagonal shape and average size was less than $09 \mathrm{~nm}$. FTIR revealed the presence of biomolecules which act as reduction and capping agent for the synthesis of ZnO NPs. Antibacterial activity of the synthesized nanoparticles against four different pathogenic (gram positive and gram negative) strains showed clear zone of inhibitions that confirm the potency of nanoparticles as an antibacterial agent. The present work explored the potential of the callus as bio-reduction material for nanoparticles synthesis.
\end{abstract}

Keywords Callus $\cdot$ Nanoparticles $\cdot$ Zinc oxide $\cdot$ XRD $\cdot$ FTIR $\cdot$ SEM $\cdot$ Antimicrobial activity

\section{Introduction}

Himalayas are known to be the treasure house of biological and cultural diversity, and regarded as the richest reservoirs of biodiversity in the world. The Indian Himalayas besides having rich diversity of plants which amounts to 8644 plant species [54] also has a repository of 1748 valuable medicinal plants $[29,67]$. The unique diversity of medicinal plants in the Himalayan region is manifested by the presence of a number of native (31\%), endemic (15.5\%) and threatened elements $[48,57]$. The description of these Himalayan medicinal plants can be found in Ayurveda, Unani and other traditional systems of medicine, and in Tibetan system of medicine as well [57]. Almost $90 \%$ of medicinal plant species are collected from wild through

$\triangle$ Arun Kumar Khajuria, arun.khajuria20@gmail.com | ${ }^{1}$ Plant Tissue Culture Laboratory, Department of Botany, H.N.B. Garhwal University, Pauri Campus, Pauri (Garhwal), Uttarakhand 246001, India. ${ }^{2}$ Department of Botany, Government Degree College Kathua, Kathua (Jammu and Kashmir) 184104, India. ${ }^{3}$ Department of Chemistry, H.N.B. Garhwal University, Pauri Campus, Pauri (Garhwal), Uttarakhand 246001, India.

SN Applied Sciences (2019) 1:455 | https://doi.org/10.1007/s42452-019-0426-3

Received: 13 February 2019 / Accepted: 27 March 2019 / Published online: 15 April 2019 
destructive harvesting, threatening their existence [12, 20, 52].

Viola canescens Wall ex. Roxb. (vernacular-Banafsha; English name-Himalayan white violet; Family-Violaceae) is a popular ethnomedicinal plant throughout Himalayas $[1,50,51]$ as the plant is used against almost every ailment either solitary or with some other plant/s. Different parts of the plant are used against common cold and also acts as antipyretic, analgesic and anti-constipating agent [10], anti-septic [50], and treat jaundice to cancerous and neurological disorders $[23,31,39,51,55]$. This potency of plant is due to the presence of several heterogeneous phytochemicals present in them, which is confirmed by methanolic and ethanolic extracts of plant used for phytochemical profile screening $[10,50]$. The plant has been investigated for number of activities and it has been found that solvent extract of Viola canescens has antioxidant, hepatoprotective activity [34], antibacterial [49], antifungal [53] and antimalarial activity [75]. Zinc based nanoparticles showed antimicrobial activities against Staphylococcus aureus and Escherichia coli [31], Staphylococcus aureus, Streptococcus pneumonia, Klebsiella pneumoniae and Escherichia coli [33].

Nanotechnology is one of the emerging branches of interest in almost all fields' right from the agriculture to medicine sector. Nanoparticles due to their large surface area, wide gap between valence and conduction band, and high fraction of surface atoms exhibit atom like behaviour $[8,61,64,65,68,71,73]$. Nanotechnology is based on the manipulation of individual atom or molecule by two different approaches viz. "top down" i.e., by reducing or size reduction of starting material [41] and "bottom up" i.e., by joining atoms, molecules and tiny particles $[21,42$, 45]. These methods are used to produce nanoparticles in the range of 1-100 $\mathrm{nm}$ because nanoparticles of this range are in high demand and also at this nano level they show improved characters over their source material $[9,30,40$, $70,72]$. Physical and chemical methods of nanoparticles synthesis required toxic chemicals as capping agents to maintain stability and ultimately lead to environmental toxicity either directly or indirectly.

Zinc oxide, a multi-tasking metal oxide, has a unique optical and electrical property. Their nanoparticles are semiconductors that crystallize in either hexagonal wurtzite or cubic zinc blend structure and display significant optical transparency and luminescent properties. Green nanotechnology use "bottom up" method to reduce the material to its nano-size. Green synthesized $\mathrm{ZnO}$ nanoparticles ( $\mathrm{ZnO} N \mathrm{NP}$ ) are preferred and has drawn worldwide interest due to some of their facilitating properties i.e., biocompatible, biodegradable, less hazardous, non-toxic, eco-friendly and wide range of applicability in different fields as Agriculture, medical, electronic, optic and other material sciences etc. In medicine, ZnO NPs has been reported as more toxic among all other metal based nanoparticles for antimicrobial assay [19, 27, 56]. Further, they are easy, inexpensive, and safe to prepare, even US FDA, considered and enlisted ZnO NPs as "Generally recognized as safe" (GRAS) metal oxides [4].

Due to the eco-friendly nature, cost effectiveness and high utility, green nanotechnology attracts a large section of researchers to think, work and explore different novel methods for the synthesis of green nanoparticles. Green nanotechnology also has biodiversity conservation implications because large amount of herbal material is required for their synthesis which may lead to the extinction of a plant especially those species which are already rare, endangered and threatened as almost $95 \%$ of the medicinal plants used by the industries are collected from the forests. As per Balakrishnan et al. [7] presently in India less than 20 plant species are under commercial cultivation whereas over 400 species used for industries production are wild populations.

Callus consist a mass of loosely arranged thin walled parenchymatous cells arising from the proliferating cells of the explants. Callus, in plant tissue culture, acts as precursor for the different organs but is also cultured and harvested for secondary metabolites. Medicinal plants offer alternative remedies with tremendous opportunities. Hence an alternative technique to explore the potential of callus or their bio-molecule to act as plant material for green biosynthesis of ZnO NPs was attempted.

Number of researcher's have reported the synthesis of ZnO NPs employing plant as a biological material viz., Aloe barbadensis [58]; Catharanthus roseus [13]; Vitex negundo [6]; Rosa canina [26]; Laurus nobilis L. [22]. Besides, only few reports are available for callus mediated biosynthesis of nanoparticles, Linum usitatissiumum callus mediated $\mathrm{ZnO}$ NPs by Abbasi et al. [2]; Allophylus serratus callus mediated Silver nanoparticles by Jemal et al. [28]. The present study reports for the first time synthesis, characterization and anti-microbial activity of ZnO NPs using Viola canescens callus extract and Zinc nitrate.

\section{Materials and methods}

\subsection{Plant material and callus induction}

Callus induction and plant regeneration is an indirect pathway of plant tissue culture, which involves aseptical culturing of the explant on suitable culture medium to regenerate complete plantlet. Murashige and Skoog medium with $3 \%$ Sucrose $(\mathrm{w} / \mathrm{v})$ as carbon source and $0.8 \% \mathrm{Agar}(\mathrm{w} / \mathrm{v})$ as gelling agent to solidifie culture medium was used in the present work. To maintain aseptic culture conditions, 
the culture medium was autoclaved at $121{ }^{\circ} \mathrm{C}$ and 15 Pascal pressure. The $\mathrm{pH}$ of the medium was adjusted to $5.8 \pm 0.2$ prior to autoclave. All cultures were maintained at $25 \pm 2{ }^{\circ} \mathrm{C}$ and $16-8 \mathrm{~h}$, temperature and photoperiod respectively, the humidity of the culture room was maintained at 60-70\%. 2,4-D, NAA (auxin) and Kn (cytokinin) were used as growth regulators for callus induction during the present work. Plants of Viola canescens were collected from its natural habitat, i.e., Nag Dev forest range Pauri, Uttarakhand, India without affecting the plants. The explants were rinsed with lukewarm water with 2-3 drops of liquid soap with constant stirring for $10 \mathrm{~min}$, followed by adding 2 drops of Tween- 20 and again stirring it for $5 \mathrm{~min}$ and finally washed under running tap water for $15 \mathrm{~min}$. Washed explants were diped in $1500 \mathrm{ppm}$ antifungal (Bavistin) solution for 30 min before washing again with the autoclaved distilled water. The surface sterilization of plants was carried out under laminar air chamber, $0.1 \%$ mercury chloride solution $\mathrm{w} / \mathrm{v}$ was used for $90 \mathrm{~s}$ and then washed repeatedly with double distilled autoclaved water for 3 times. Sterilized explants were trimmed with the help of scalpel and inoculated in callus inducing medium for calli initiation [32].

\subsection{Extract preparation}

Leaf and petiole explants derived calli were served as source of callogenesis during the work. The 40-45 days old Calli were harvested aseptically under laminar air flow chamber for the preparation of extract. Callus extract was prepared by following the methodology of Abbasi et al. [2] with modification. Harvested calli weigh $12 \mathrm{~g}$ (fresh weight) and then soaked in $100 \mathrm{ml}$ of double distilled water. The mixture was then heated for $30 \mathrm{~min}$ at constant temperature on hot plate at $60^{\circ} \mathrm{C}$ followed by incubating the mixture at $40^{\circ} \mathrm{C}$ for $24 \mathrm{~h}$ before heating the mixture again at $60^{\circ} \mathrm{C}$ twice at the interval of $1 \mathrm{~h}$ and finally allowed to cool at room temperature. The solution obtained was then filtered with muslin cloth followed by with whatman filter paper twice. The volume of the filtrate was increased to $100 \mathrm{ml}$ with the help of double distilled water.

\subsection{Biosynthesis of $\mathrm{Zn}$ nanoparticles}

Biosynthesis of $\mathrm{Zn}$ nanoparticles was done by mixing $100 \mathrm{ml}$ of callus extract with $100 \mathrm{ml}$ of zinc nitrate extract in $500 \mathrm{ml}$ flask. Prepared plant extract was heated at $60{ }^{\circ} \mathrm{C}$ with constant stirring using magnetic stirrer for $10 \mathrm{~m}$ before adding $\mathrm{ZnO}$ extract in the flask slowly. After complete pouring of the $\mathrm{Zn}$ extract in flask having plant extract, the mixture of both solutions was kept for vigorous stirring at $60{ }^{\circ} \mathrm{C}$ for $4 \mathrm{~h}$. The change in colour of solution was considered as visual marker for the synthesis of nano particles. Synthesis of nanoparticles was confirmed by UV-visual analysis. Further, the precipitate starts appearing after $3 \mathrm{~h}$ of vigorous stirring at $60^{\circ} \mathrm{C}$. Precipitate formed in reaction was allowed to settle at room temperature for $24 \mathrm{~h}$. Supernatant was discarded and crude was centrifuged for $20 \mathrm{~min}$ at $5000 \mathrm{rpm}$, again supernatant were discarded and formed pellets were washed thrice with double distilled water. Finally, pellets were oven dried at $70^{\circ} \mathrm{C}$ for $10 \mathrm{~h}$ followed by mashing in mortar and pestle to get fine powder and stored in air tight bottles for further characterization and anti-microbial activities.

\subsection{Characterization of $\mathrm{ZnO}$ nanoparticles}

The synthesis of Zinc nanoparticles was confirmed preliminarily by visual observations, including the change of the solution colour from creamy white to light yellow and finally to dark yellow after heating for an hour.

\subsection{XRD analysis}

The crystalline nature, phase variety and the grain size of synthesized nanoparticles were investigated by XRD (X-ray diffraction) spectroscopy studies. XRD analysis of synthesized nanoparticles was carried out by coating it on XRD grid and measurements were performed in the scanning mode, in the range of $0^{\circ}-65^{\circ}$ at $2 \theta$. The size of the sample was calculated by Deby-Scherrer's equation as follows:

$D=\frac{K \lambda}{\beta 1 / 2 \cos \theta}$

where $D$ is an average size of crystallite; $\beta$ is full width at half maximum of the peak in radians; $\lambda$ is wavelength of X-ray; $\theta$ is Bragg's angle and $K$ is constant (geometric factor $=0.94$ ).

\subsection{Scanning Electron Microscopy (SEM) analysis}

The SEM analysis of the synthesized nanoparticles was carried out by preparing a film of SEM grid by dry powder (sample) on a carbon coated copper grid by dropping simply a very small amount of sample on the grid. The carbon coated copper grids (the films) were then allowed to dry under a mercury lamp and SEM images were recorded at different magnifications.

\subsection{Fourier Transform Infrared Spectroscopy (FTIR) analysis}

The chemical or biomolecules involved in the bio- reduction and capping of the nanoparticles was analysized by 
Fourier Transform Infrared Spectroscopy and recorded in the range of $4000-500 \mathrm{~cm}^{-1}$.

\subsection{Anti-bacterial assay}

Synthesized Zinc nanoparticles were subjected to antibacterial assay against four clinically isolated strains viz., Staphylococcus aureus, Streptococcus pneumonia, Klebsiella pneumoniae and Escherichia coli, by Agar well diffusion method. During the work Muller Hinton Agar Medium (HIMedia) was used as culture medium for bacterial assay. The medium was prepared by dissolving $33.9 \mathrm{gm}$ of MHA into $1000 \mathrm{ml}$ of distilled water followed by its autoclaving at $121^{\circ} \mathrm{C}$ temperature and 15 Pascal pressure for $15 \mathrm{~m}$. To avoid any contamination, the entire work was carried out under laminar air chamber.

\subsection{Statistical analysis}

All experiments for antibacterial assay were conducted in replicates and data pooled from 3 independent experiments. The effect of different concentrations and treatments was analyzed using one-way analysis of variance (ANOVA), and difference between their means was compared using Duncan's Multiple Range Test (DMRT), a post hoc test, at $P<0.05$. All the analysis was carried out using SPSS 16.0 .

\section{Result and discussion}

\subsection{Callus induction and proliferation}

Callus, the undifferentiated mass of loosely arranged thin walled parenchymatous cells, arising from the proliferating cells of the parent tissue is precursor of different organs in micropropagation. Callus culture of the plant produces the same compound the plant have or more over they have capacity to produce the chemicals at higher rate the plant produces $[16,43]$. Callus obtained from an explant of the plant by culturing it on culture media fortified with different plant growth regulators (PGRs). The callus culture provides all weather and continuous sterilized, reliable large scale source of plant material for the synthesis of nanoparticles or for other purposes (production of secondary metabolite, extraction of some useful compounds etc.).

The sterilized explants were inoculated on culture medium under control conditions. The inoculated cultures showed calli formation from the cut end of the explants after 8-14 days in maximum concentrations and combinations. MS medium without regulators was used as control and explants showed no calli formation. Similar results were also reported in some other plant species i.e., Psoralea corylefolia [60], Salvia canariensis [44] and Dorema ammoniacum [25]. In second set of experiment, MS medium fortified with 2,4-D and NAA. NAA alone cannot induce calli in explants or occasionally swelling followed by no callus formation is reported when medium was fortified with higher concentrations of NAA. While 2,4-D even in lower concentrations start producing calli in both explants with maximum callus induction frequency $(43.33 \pm 0.50)$ and $(53.33 \pm 0.52)$ for leaf and petiole explants when MS medium was fortified with 6.78 and $13.56 \mu M$ 2,4-D, respectively. In third set of experiment, 2-4-D:Kn and NAA:Kn combinations was tried and maximum callus induction frequency (CIF) for leaf explants was $96.67 \pm 0.11$ when the medium was fortified with 2,4-D:Kn $(6.78+6.97 ; 6.78+9.30 \mu \mathrm{M})$ while for the petiole explants the maximum CIF was $96.67 \pm 0.11$ when the culture medium was fortified with $9.04+9.30 \mu \mathrm{M}$ 2,4-D:Kn. But when NAA:Kn combinations was tried, maximum average CIF for leaf and petiole explants was observed to be $80.00 \pm 0.33 ; 80.00 \pm 0.18$ and $86.67 \pm 0.30 ; 86.67 \pm 0.18$ for $10.74+6.97$; $10.74+9.30 \mu \mathrm{M}$ and $10.74+9.30 ; 13.42+6.97 \mu \mathrm{M}$, respectively. Figure 1 and 2, shows the interactions of growth

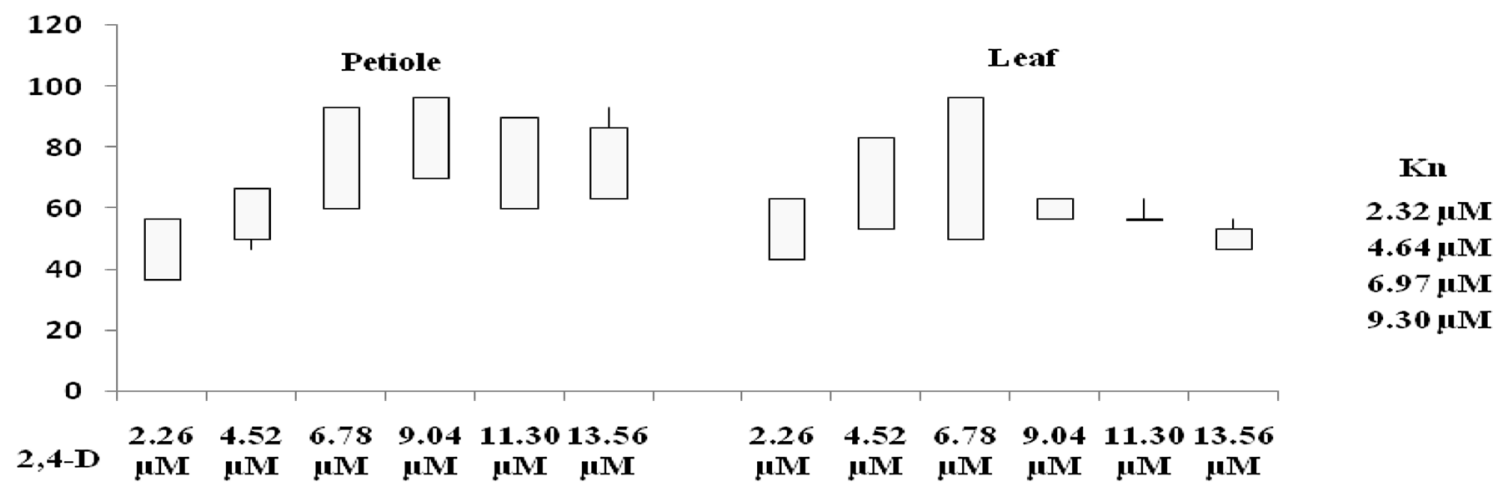

Fig. 1 Callogenesis responses for callus induction frequency in petiole and leaf explants of Viola canescens on MS Medium with 2,4-D, 2,4-D+Kn

SN Applied Sciences 
regulators for CIF when combinations of 2,4-D:Kn and $\mathrm{NAA}: \mathrm{Kn}$ was tried and it was observed that $6.78 \mu \mathrm{M}$ 2,4-D concentration with different $\mathrm{Kn}$ concentrations $(2.32-9.30 \mu \mathrm{M})$ was proved superior to the other combinations for leaf explant, while 9.04 2,4-D with different Kn concentrations (2.32-9.30 $\mu \mathrm{M})$ proved superior for petiole explant. Further, in both cases increasing concentration from 2.32 to $9.30 \mu \mathrm{M}$ showed positive increase in CIF. For NAA $10.74 \mu \mathrm{M}$ with different concentration of $\mathrm{Kn}$ was proved superior than the other concentrations and combination of NAA:Kn for both explants (Fig. 3).

In case of calli proliferation, best calli for 2,4-D: Kn combination were seen in $6.78+4.64,6.78+6.97,6.78+9.30$ and $9.04+6.97 \mu \mathrm{M}$ for leaf explants (Table 1), while for the petiole explants when the medium was fortified with $6.78+6.97,6.78+9.30,9.04+6.97,9.04+9.30$ and

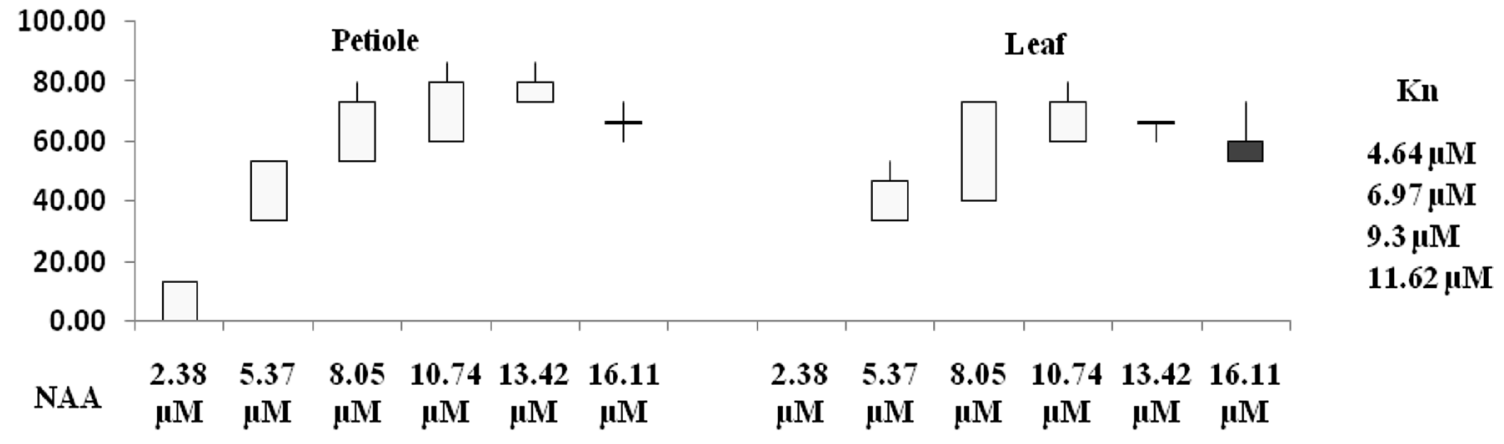

Fig. 2 Callogenesis responses for callus induction frequency in Petiole and Leaf explants of Viola canescens on MS Medium with NAA, $\mathrm{NAA}+\mathrm{Kn}$

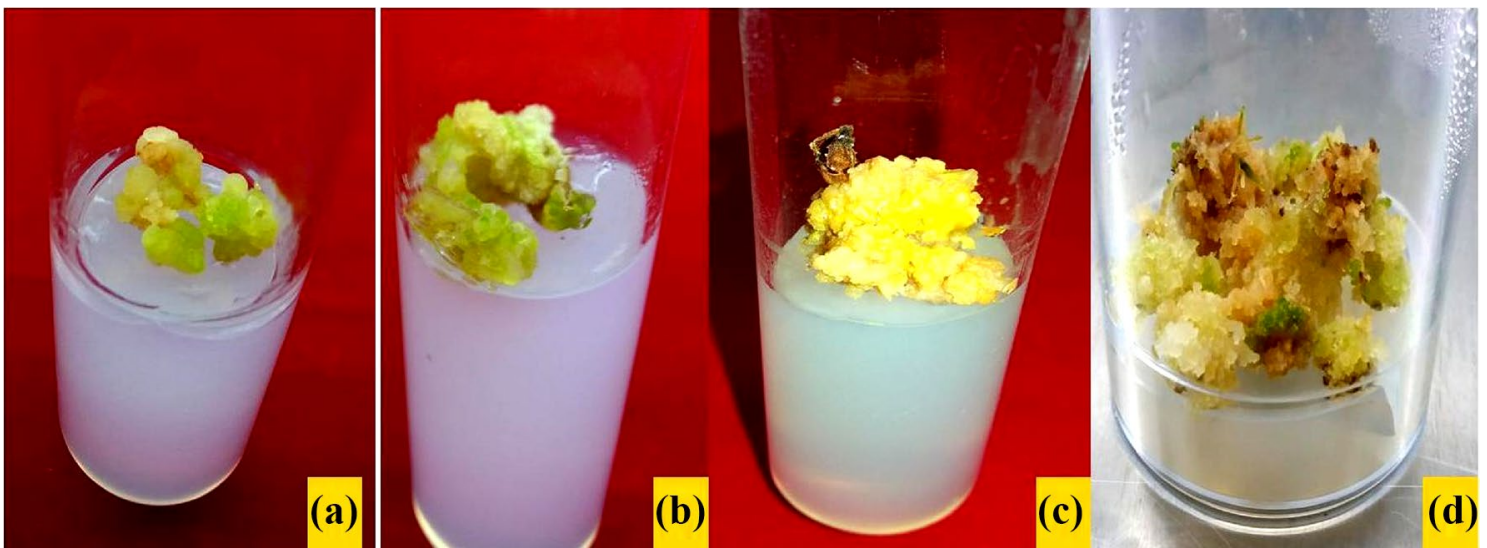

Fig. 3 Callus induction from petiole explant (a); callus induction from leaf explant (b and $\mathbf{c}$ ); 40 day old callus for extract preparation (d)

Table 1 Callogenesis responses for calli proliferation in leaf explant of Viola canescens on MS medium with or without growth regulators

\begin{tabular}{llllllll}
\hline $\mathrm{Kn}(\mu \mathrm{M})$ & $2,4-\mathrm{D}(\mu \mathrm{M})$ & & & & & \\
\cline { 2 - 7 } & $0.00 \mu \mathrm{M}$ & $2.26 \mu \mathrm{M}$ & $4.52 \mu \mathrm{M}$ & $6.78 \mu \mathrm{M}$ & $9.04 \mu \mathrm{M}$ & $11.30 \mu \mathrm{M}$ & $13.56 \mu \mathrm{M}$ \\
\hline 0.00 & - & + & + & + & ++ & + & ++ \\
2.32 & - & + & + & ++ & + & + & + \\
4.64 & - & ++ & ++ & ++++ & +++ & +++ & ++ \\
6.97 & - & +++ & +++ & ++++ & ++++ & +++ & +++ \\
9.30 & - & ++ & +++ & ++++ & +++ & +++ & ++ \\
\hline
\end{tabular}

- No callus, + poor, ++ good, +++ better, ++++ best

Callus proliferation from leaf explants of $V$. canescens Growth period 5 weeks 
$11.30+4.64 \mu \mathrm{M}$ yielded best callus mass while other combinations tried responded poor to good for callus proliferation (Table 2). In case of NAA:Kn interactions, for callus proliferation no best callus growth was reported, but good callus growth was found when the higher concentration of both growth regulators were tried. Petiole explants responded differently and best calli proliferations were observed only when growth regulators were used at very high concentrations $(13.42+11.62$ and $16.11+11.62 \mu \mathrm{M})$, while other concentrations responded good to better in other combinations (Tables 3, 4).

It was further observed that, 2,4-D showed good proliferation results and intermediate concentrations (among the various concentration tried in present work) responded best, while higher concentration proved inferior for both callus induction and proliferation, the results are in correlation with the work of Malik et al. [38], Sheeba et al. [66]. The proliferation of calli, with NAA:Kn concentrations was inferior than 2,4-D:Kn similar to Bhandari [11] and Bisht [14]. The generated calli were then maintained on the same culture medium and harvested after 5-6 weeks.

\subsection{X-ray diffraction (XRD)}

X-ray diffraction technique for studying crystal structure is based on discovery of Laue [35] that crystalline substances act as a three dimensional diffraction grating for $X$-ray wavelength [18]. X-ray diffraction is an important versatile, non-destructive analytical method used for identification and quantitative determination of various
Table 2 Callogenesis responses for calli proliferation in petiole explant of Viola canescens on MS medium with or without growth regulators

Table 3 Callogenesis responses for calli proliferation in leaf explant of Viola canescens on MS medium with or without growth regulators

Table 4 Callogenesis responses for calli proliferation of leaf explant of Viola canescens on MS medium with or without growth regulators

\begin{tabular}{llllllll}
\hline $\mathrm{Kn}(\mu \mathrm{M})$ & \multicolumn{2}{l}{$2,4-\mathrm{D}(\mu \mathrm{M})$} & & & & & \\
\cline { 2 - 7 } & $0.00 \mu \mathrm{M}$ & $2.26 \mu \mathrm{M}$ & $4.52 \mu \mathrm{M}$ & $6.78 \mu \mathrm{M}$ & $9.04 \mu \mathrm{M}$ & $11.30 \mu \mathrm{M}$ & $13.56 \mu \mathrm{M}$ \\
\hline 0.00 & - & + & + & + & ++ & ++ & ++ \\
2.32 & - & + & + & + & + & ++ & ++ \\
4.64 & - & ++ & ++ & +++ & +++ & ++++ & +++ \\
6.97 & - & ++ & +++ & ++++ & ++++ & +++ & +++ \\
9.30 & - & ++ & +++ & ++++ & ++++ & +++ & +++ \\
\hline
\end{tabular}

- No callus, + poor, ++ good, +++ better, ++++ best

Callus proliferation from petiole explants of $V$. canescens

\begin{tabular}{llllllll}
\hline $\mathrm{Kn}(\mu \mathrm{M})$ & \multicolumn{7}{l}{$\mathrm{NAA}(\mu \mathrm{M})$} \\
\cline { 2 - 7 } & $0.00 \mu \mathrm{M}$ & $2.68 \mu \mathrm{M}$ & $5.37 \mu \mathrm{M}$ & $8.05 \mu \mathrm{M}$ & $10.74 \mu \mathrm{M}$ & $13.42 \mu \mathrm{M}$ & $16.11 \mu \mathrm{M}$ \\
\hline 0.00 & - & - & - & - & - & - & \\
2.32 & - & - & + & + & + & + & + \\
4.64 & - & - & + & ++ & + & ++ & ++ \\
6.97 & + & - & + & ++ & ++ & ++ & ++ \\
9.30 & - & - & + & ++ & ++ & +++ & ++ \\
11.62 & - & - & + & ++ & ++ & +++ & +++ \\
\hline
\end{tabular}

- No callus, + poor, ++ good, +++ better, ++++ best

Callus proliferation from leaf explants of $V$. canescens

\begin{tabular}{|c|c|c|c|c|c|c|c|}
\hline \multirow[t]{2}{*}{$\mathrm{Kn}(\mu \mathrm{M})$} & \multicolumn{7}{|c|}{ NAA $(\mu \mathrm{M})$} \\
\hline & $0.00 \mu \mathrm{M}$ & $2.68 \mu \mathrm{M}$ & $5.37 \mu \mathrm{M}$ & $8.05 \mu \mathrm{M}$ & $10.74 \mu \mathrm{M}$ & $13.42 \mu \mathrm{M}$ & $16.11 \mu \mathrm{M}$ \\
\hline 0.00 & - & - & - & - & - & - & - \\
\hline 2.32 & - & + & + & + & + & ++ & ++ \\
\hline 4.64 & - & + & + & + & ++ & ++ & ++ \\
\hline 6.97 & - & + & + & ++ & ++ & +++ & +++ \\
\hline 9.30 & - & + & + & + & +++ & +++ & +++ \\
\hline 11.62 & - & + & ++ & ++ & +++ & ++++ & ++++ \\
\hline
\end{tabular}

- No callus, + poor, ++ good, +++ better, ++++ best

Callus proliferation from petiole explants of $V$. canescens 


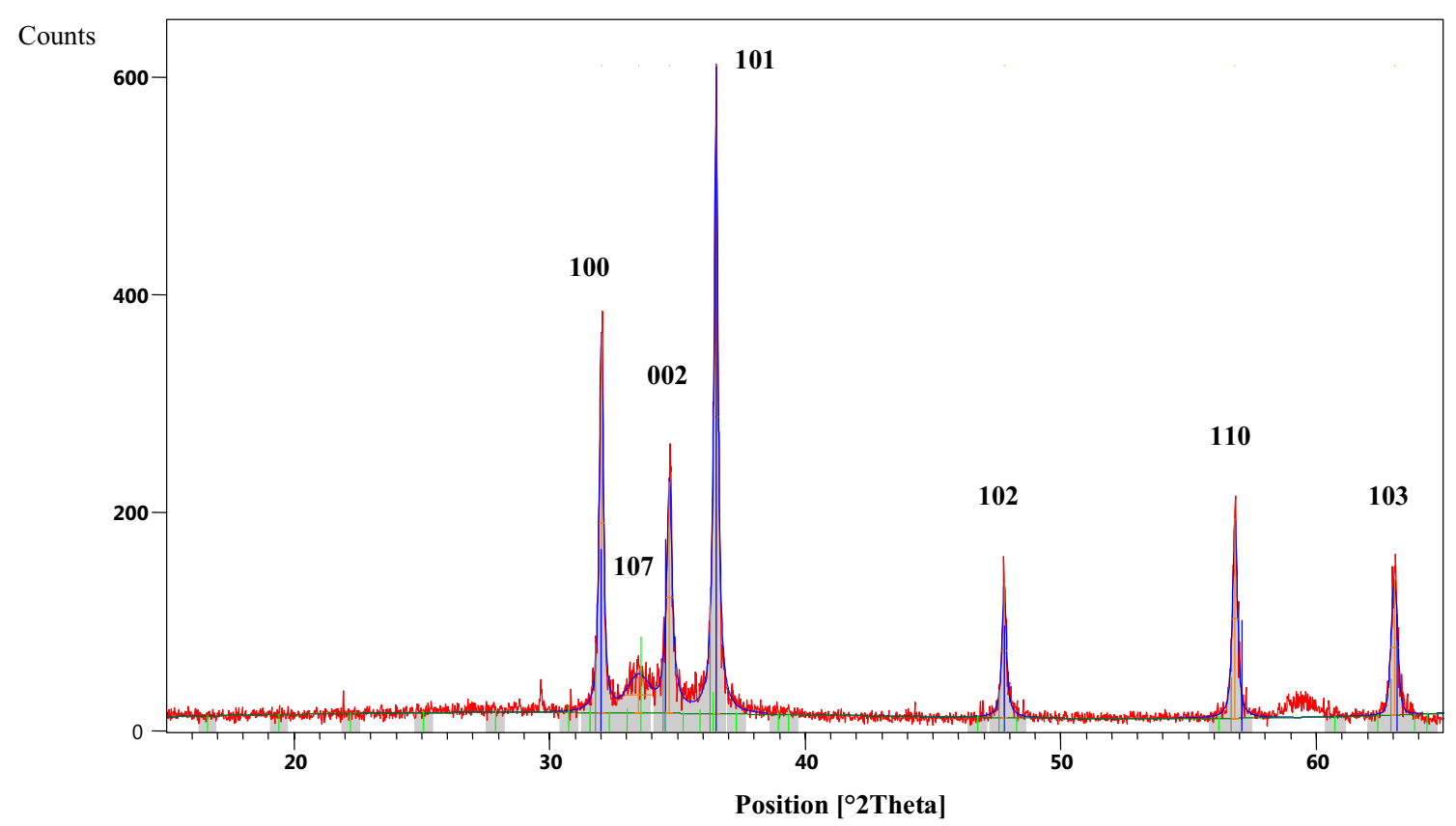

Fig. 4 XRD spectrogram of calli based synthesized $\mathrm{ZnO}$ nanoparticles

Table 5 Peak list for average size calculation of nanoparticles

\begin{tabular}{llllc}
\hline Pos. ["2Th.] & Hkl & $\begin{array}{l}\text { FWHM Left } \\
\text { [²Th.] }^{\circ}\end{array}$ & d-spacing [Å] & Rel. Int. [\%] \\
\hline 32.031 & 100 & 0.19 & 2.79202 & 63.83 \\
33.480 & 107 & 1.05 & 2.67416 & 5.91 \\
34.690 & 002 & 0.26 & 2.58384 & 38.96 \\
36.516 & 101 & 0.197 & 2.45867 & 100.00 \\
47.788 & 102 & 0.20 & 1.90175 & 22.65 \\
56.819 & 110 & 0.23 & 1.61905 & 33.50 \\
63.061 & 103 & 0.30 & 1.47298 & 22.89 \\
\hline
\end{tabular}

crystalline forms of solids, including lattice constant and geometry. An interaction of a particular crystalline solid with X-rays helps in investigating its actual structure. The XRD spectrometric analysis of in vitro callus based synthesis of nanoparticles using Zinc nitrate hexahydarate as precursor of $\mathrm{Zn}$ ions (Fig. 4), showed distinctive peaks at 32.031, 33.480, 34.690, 36,516, 47.788, 56.819 and 63.06, which corresponds to lattice plane of 100 , $107,002,101,102,110$ and 103, respectively and confirms the crystallinity with hexagonal structure of synthesized nanoparticle. The average calculated size of ZnO NPs were obtained from most prominent XRD peaks by using Deby- Scherrer's equation and was recorded to be $<9 \mathrm{~nm}$ (Table 5). A few unassigned peaks were also observed which may be due to the presence of some bioorganic compounds/protein(s) in the callus extracts and crystallizes on the surface of zinc, similar finding was also reported by Ahmad \& Sharma [5], during their study they reported the unassigned peaks in the XRD spectra which might be due to the crystallization of proteins or other biomolecules on the surface of silver from the leaf extract of Ananas comosus [5]. Further, similar results were also reported for silver nanoparticles synthesized by using Geranium leaves [63], Mangifera indica leaf extract [47] and Coleus aromaticus leaf extract [74].

\subsection{Fourier Transform Infrared Spectroscopy (FTIR)}

FTIR is performed to determine the different functional groups present in the sample, because absorption results in the change in vibrational and rotational state of molecular bonds and different functional groups absorb characteristic frequencies of infrared radiations. Thus, producing spectra with different peaks, which corresponds to frequency of vibration between the bonds of atoms that makes the molecule, providing unique characteristic of the functional groups that make up the molecules and of the overall configuration of the molecule. FTIR spectra obtained from the powder sample of the synthesized nanoparticles showed number of peaks (Fig. 5) which corresponds to hydroxyl group $\left(3421.34 \mathrm{~cm}^{-1}\right), 2419.33 \mathrm{~cm}^{-1}$ peak which is attributing phosphin, further peaks at $2140.10 \mathrm{~cm}^{-1}, 1648.03 \mathrm{~cm}^{-1}, 1555.80 \mathrm{~cm}^{-1}, 1384.10 \mathrm{~cm}^{-1}$ and $1056.46 \mathrm{~cm}^{-1}$ which again corresponds to $C \equiv C, C=C$, $\mathrm{C}=\mathrm{O}$ and $\mathrm{C}-\mathrm{O}$, respectively. Besides, band at 545.65 attributed to $\mathrm{ZnO}$ hexagonal structure. Hence, from the results 


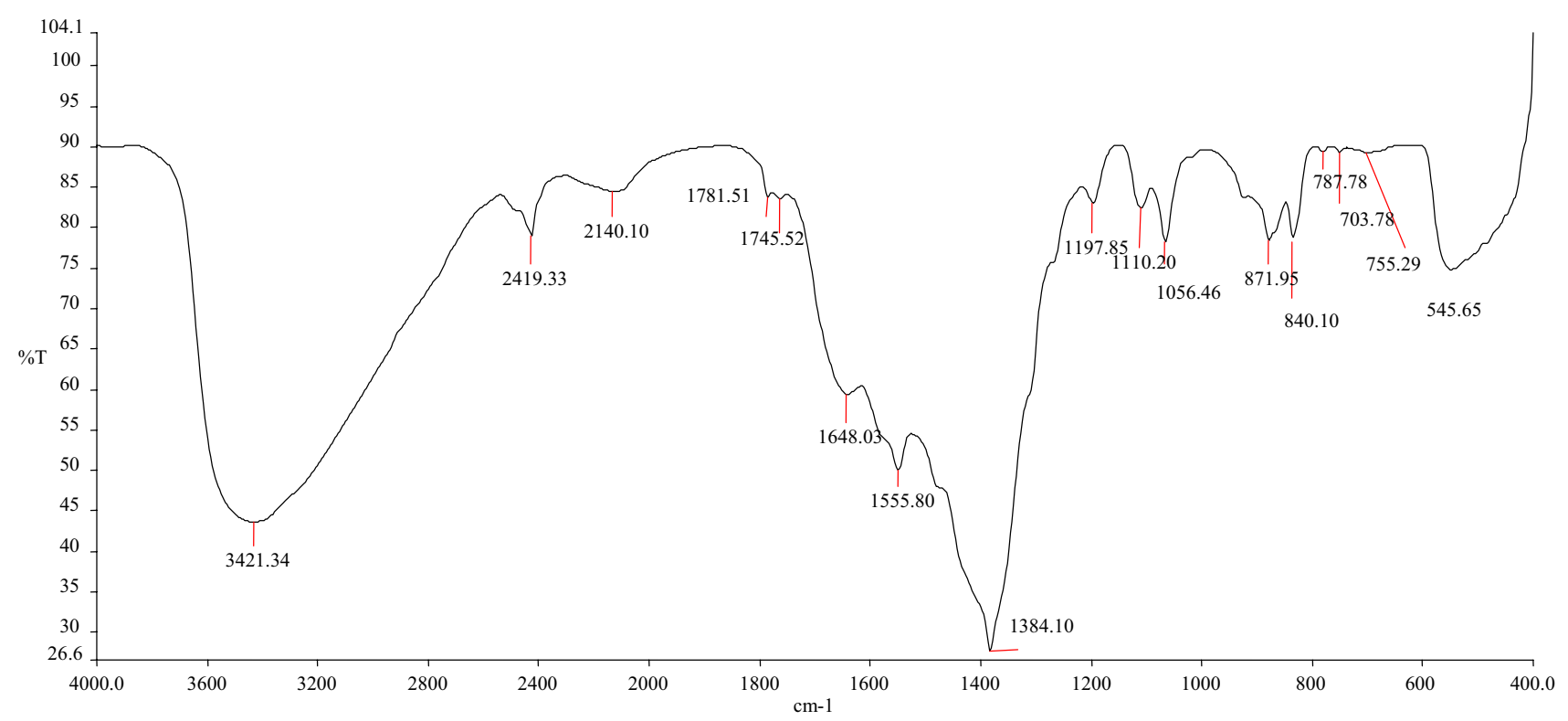

Fig. 5 FTIR of callus based $\mathrm{ZnO}$ nanoparticles

of FTIR, it is confirmed that some biomolecules form the callus extract such as phenols, alkaloids, flavonoids and other biomolecules served as fuel for the bio-reduction and capping of ZnO to its nano-size or ZnO NPs (Fig. 6).

\subsection{Scanning Electron Microscopy (SEM) analysis}

SEM is a type of microscopy that produces high resolution images of sample surface by using focused beam of high energy electrons. Thus specimen was exposed to beam of electron which moved over and scan the surface of the specimen. SEM analysis for morphological studies was carried out on prepared films grids and the micrographs were obtained at different magnifications i.e., $900 \times$ to $6000 \times$ at 10-15 kv. Biosynthesized ZnO NPs were rod shaped in morphology, moreover boundaries between each particle can be observed easily (Fig. 7). Further, morphology of nanoparticles appeared nearly hexagonal in shape which is in accordance with the XRD results.

\subsection{Anti-bacterial assay}

Nanoparticles shows enhanced anti-bacterial activity in comparison to their bulky cousins, which might be attributed to large surface area over volume. Agar well diffusion method was used to evaluate the bactericidal activity of synthesized nanoparticles against 2 gram positive (Streptococcus pneumoniae and Staphylococcus aureus) and 2 gram negative (Klebsiella pneumoniae and E. coli) bacteria. During assay sodium chloride solution was used as positive control and Amoxicillin was used as the drug, for the comparative response. Synthesized ZnO NPs showed antimicrobial potential against all test organisms. The maximum zone of inhibition was reported in Klebsiella pneumoniae $(13.90 \pm 0.17 \mathrm{~mm})$ when $100 \mu \mathrm{g} \mathrm{ZnO}$ nanoparticles were put in the well and minimum zone of inhibition was reported in E. coli $(11.53 \pm 0.38)$ for $100 \mu \mathrm{g}$ concentration (Table 6). Similar results were reported by Senthilkumar and Sivakumar [62] and Jemal et al. [28]. In the present work, the possible mechanism involved in the antibacterial activity of nanoparticles was thought to be production of reactive oxygen species (ROS) (Fig. 8). In culture medium small sized nanoparticles accumulate on the surface of bacteria, which then absorbed on the surface. Direct contact of ZnO NPs with the cell membrane results in the destruction of bacterial cell integrity $[3,15,69,78]$. After reaching inside the cell ZnO NPs activated and produce ROS such as hydroxyl radicals, superoxides and hydrogen peroxide $\left(\mathrm{H}_{2} \mathrm{O}_{2}\right)[37,59,77]$. Since negatively charged radicals cannot enter into the cell membrane of host, only hydrogen peroxide, a strong oxidizing agent can enter the cell membrane. After entering in the host cell it produces free radicals which interrupt the metabolism of host cell and several times damage the DNA or the cell membrane which ultimately results in the death of the organism (Fig. 8). Statistical analysis for the amount of nanoparticles dependent bactericidal activity showed significant variation by DMRT at $0.5 \%$ and maximum zone of inhibition attributed to high concentration of nanoparticles, and among different bacteria maximum zone of inhibition 
(a)
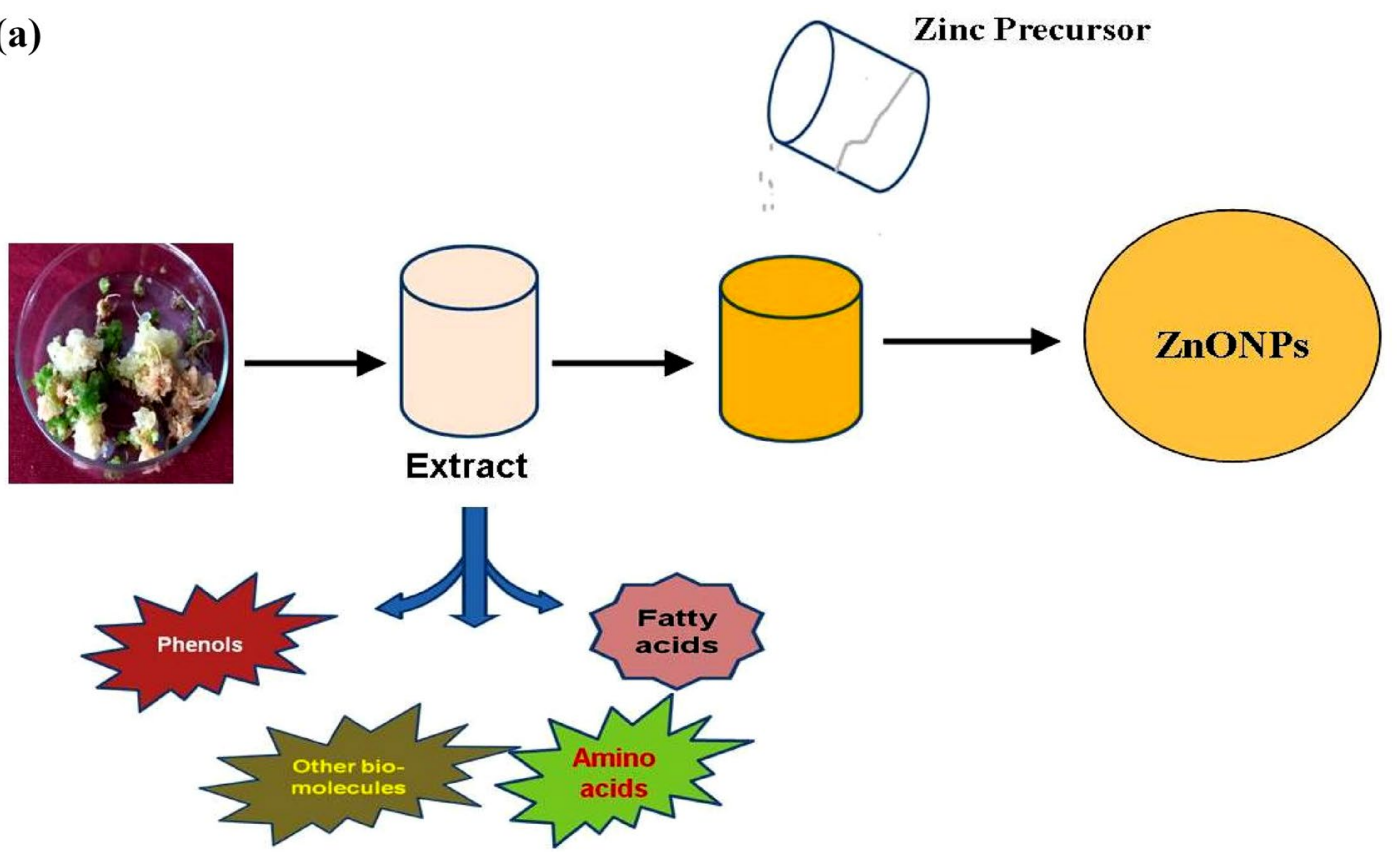

(b)
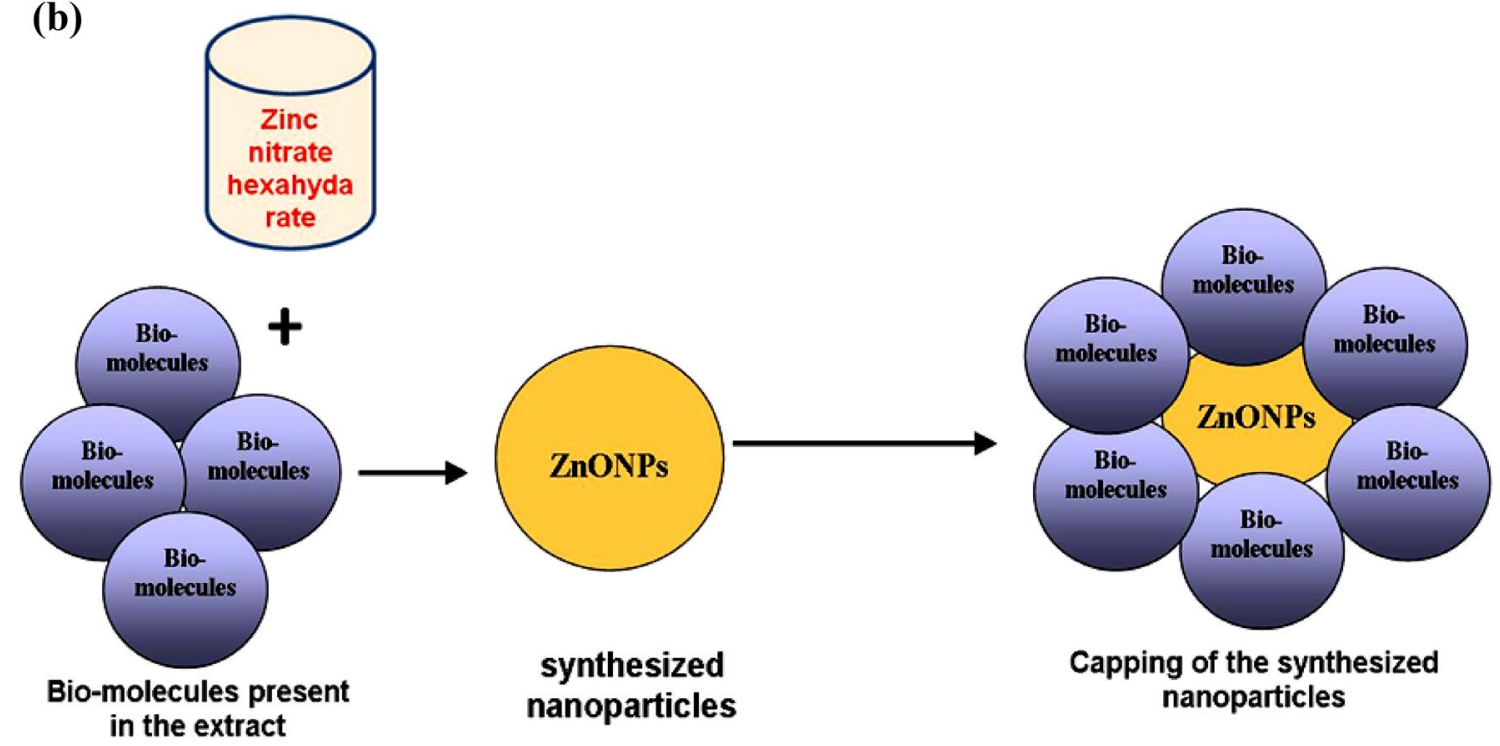

Fig. 6 Schematic representation for synthesis of ZnO NPs, a bio-reduction b bio-capping of synthesized nanoparticles by plant compounds (bio-molecules) present in the calli extract of Viola canescens

was reported for K. pneumoniae while least value for $E$. coli. Further in comparison to drug based zone of inhibition, present synthesized nanoparticles proved best over conventional drug for S. aureas. Antibacterial activity of synthesized nanoparticles mainly depend on their size and ROS is major cause of nanotoxicity [17, 24, 36, 46, 76, 79], the present finding confirm the same because leaf $(26 \mathrm{~nm})$ and root $(11 \mathrm{~nm})$ based nanoparticle proved inferior in comparison to callus based nanoparticles [31, 33] (Fig. 9).

\section{Conclusion}

The present work explored the alternative pathway for the nanoparticles synthesis, which involves the synthesis of nanoparticles using the callus of the plant in place of using 


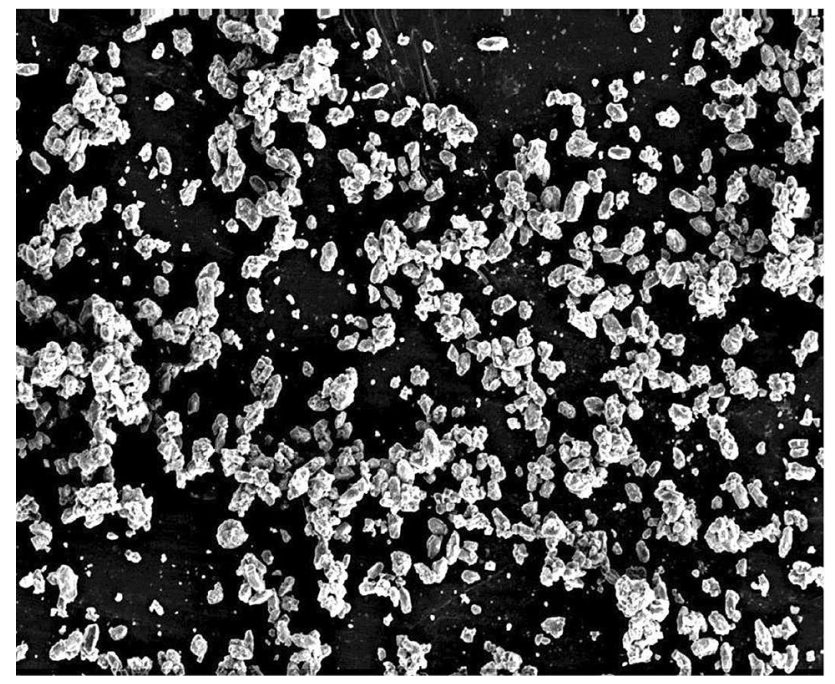

Fig. 7 SEM image of synthesized ZnO nano-particles by callus extract of Viola canescens

the organs of the plant (leaves, roots, whole plant etc.). This alternate pathway reduces the burden on the biodiversity because as per existing methodology huge amount of the plant material is required for the synthesis of metallic nanoparticles. So, nanoparticles of critically endangered or rare, endangered and threatened (RET) species of high medicinal value may be achieved by this improved methodology. Moreover, the availability of plant material is throughout the year under lab conditions through callus. The callus extract of the $V$. canescens showed the potency for the bio-reduction and capping of the ZnO NPs. The green method proved cost effective and safe practice over the chemical and physical synthesis of the nanoparticles. The XRD investigation suggested hexagonal structure with less than $9 \mathrm{~nm}$ average size of nanoparticles. The (a)

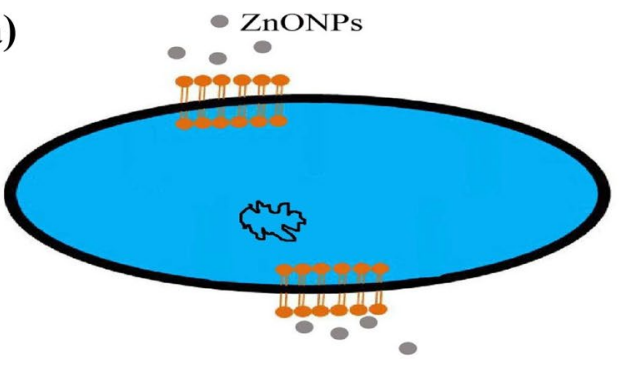

(b)

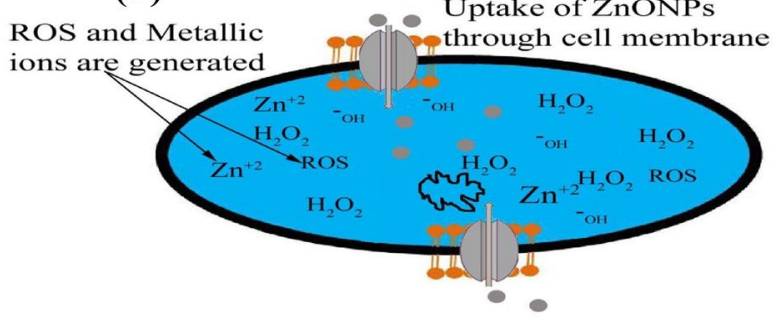

(c)

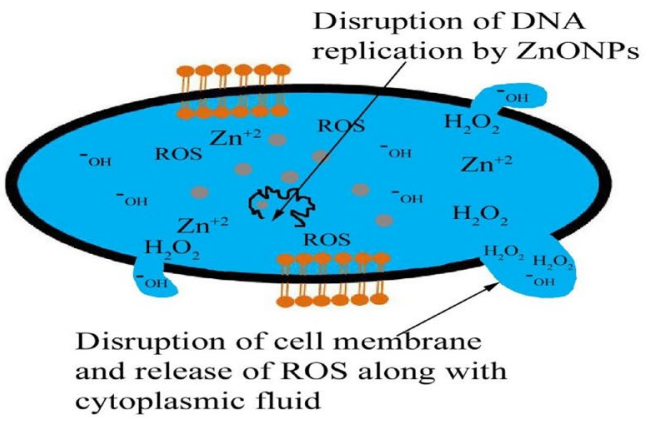

Fig. 8 Possible pathway involved in anti-bacterial activity of $\mathrm{ZnO}$ NPs (a-c); Uptake of ZnO NPs (a); Entrance of ZnO NPs through protein pumps or channels and production of ROS species (b); Disruption of cell membrane and bacterial genome due to interaction with ROS species produced from nanoparticles (c)
Table 6 Antibacterial activity of callus based $\mathrm{ZnO}$ nanoparticles against different bacterial strains

\begin{tabular}{lllll}
\hline Concentration & \multicolumn{2}{l}{ Test organisms zone of inhibition in $(\mathrm{mm})$} \\
\cline { 2 - 5 } & Staphylococcus aureus & Klebsiella pneumoniae & E. coli & $\begin{array}{l}\text { Streptococcus } \\
\text { pneumoniae }\end{array}$ \\
\hline Control & $0.00 \pm 00$ & $0.00 \pm 00$ & $0.00 \pm 00$ & $0.00 \pm 00$ \\
Drug & 9 & 15.3 & 11.7 & 15 \\
$50 \mu \mathrm{g}$ & $11.93 \pm 0.35^{\mathrm{b}}$ & $12.50 \pm 0.46^{\mathrm{b}}$ & $10.30 \pm 0.9^{\mathrm{b}}$ & $9.93 \pm 0.42^{\mathrm{b}}$ \\
$75 \mu \mathrm{g}$ & $12.60 \pm 0.46^{\mathrm{ab}}$ & $13.07 \pm 0.28^{\mathrm{ab}}$ & $10.77 \pm 0.2^{\mathrm{ab}}$ & $12.97 \pm 0.3^{\mathrm{a}}$ \\
$100 \mu \mathrm{g}$ & $13.47 \pm 0.25^{\mathrm{a}(\mathrm{A})}$ & $13.90 \pm 0.17^{\mathrm{a}(\mathrm{A})}$ & $11.53 \pm 0.38^{\mathrm{a}(\mathrm{B})}$ & $13.57 \pm 0.2^{\mathrm{a}(\mathrm{A})}$ \\
\hline
\end{tabular}

\pm Standard deviation; data polled form three independent experiments, same letter in the column and same letter in the bract of the row is non-significant different by DMRT at $(p=0.05)$ 


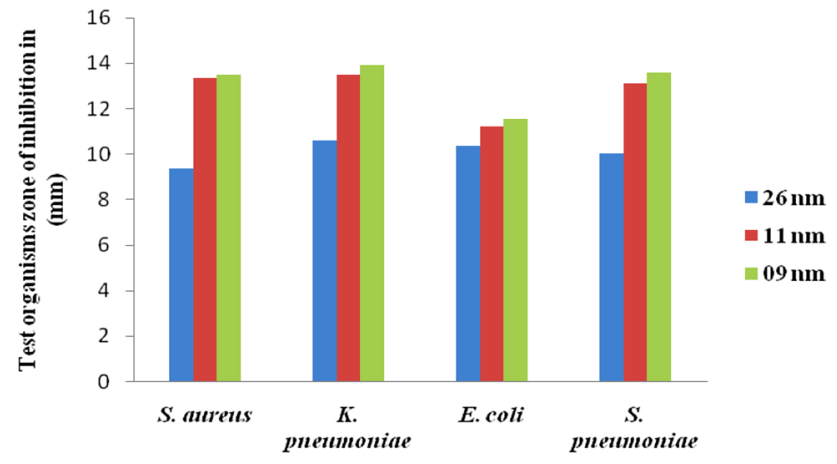

Fig. 9 Size dependent anti-microbial activity of ZnO NPs of Viola canescens; leaf extract $(<26 \mathrm{~nm})$, root extract $(<11 \mathrm{~nm})$ and callus extract $(<9 \mathrm{~nm})$

synthesized nanoparticles depicted good anti-microbial activity and showed clear zone of inhibition against all tested bacteria. Thus, present protocol may be used for the synthesis of nanoparticles using callus of other plants especially RET species.

Acknowledgements The authors are highly thankful to USIC department of HNB Garhwal University and Punjab University Chandigarh for their help during characterization of ZnO NPs and to Dr. V. Maurya for assistance in the antimicrobial aspect of the work.

\section{Compliance with ethical standards}

Conflict of interest The authors declare no conflict of interest.

\section{References}

1. Abbasi AM, Khan AM, Ahmed M, Zafar M (2010) Herbal medicines used to cure various ailments by the inhabitant of Abbottabad district, North West Frontier Province, Pakistan. Indian J Tradit Knowl 9(1):175-183

2. Abbasi BH, Anjum S, Hano C (2017) Differential effect of in vitro cultures of Linum usitatissimum L. on biosynthesis, stability, antibacterial and antileishmanial activites of Zinc oxide nanoparticles: a mechanistic approach. R Soc Chem 7:15931-15943

3. Adams LK, Lyon DY, Alvarez PJ (2006) Comparative eco-toxicity of nanoscale $\mathrm{TiO}_{2}, \mathrm{SiO}_{2}$, and $\mathrm{ZnO}$ water suspensions. Water Res 40(19):3527-3532

4. Aggarwal H, Kumar SV, Kumar RS (2017) A review on green synthesis of Zinc oxide nanoparticles-An eco-friendly approach. Resour Effic Technol. https://doi.org/10.1016/j.reffit.2017.03.002

5. Ahmad N, Sharma S (2012) Green synthesis of silver nanoparticles using extracts of Ananas comosus. Green Sustain Chem 2(04):141-147

6. Ambika S, Sundrarajan M (2015) Antibacterial behavior of Vitex negundo extract assisted $\mathrm{ZnO}$ nanoparticles against pathogenic bacteria. J Photochem Photobiol, B 146:52-57

7. Balakrishnan V, Ravindran KC, Robinson JP (2009) Effective regeneration of Impatiens campanulata weight a valuable medicinal plant from Western Ghats of Tamil Nadu, India. Glob J Pharma 3(1):41-49
8. Balgobind K, Kanchi S, Sharma D, Bisetty K, Sabela MI (2016) Hybrid of ZnONPs/MWCNTs for electrochemical detection of aspartame in food and beverage samples. J Electroanal Chem 774:51-57

9. Banerjee J, Narendhirakannan R (2011) Biosynthesis of silver nanoparticles from Syzygium cumini (L.) seed extract and evaluation of their in vitro antioxidant activities. Dig J Nanomater Biostruct 6:961-968

10. Barkatullah M, Ibrar N, Ali NM, Ehsan M (2012) In-vitro pharmacological study and preliminary biomolecule profile of Viola canescens Wall. ex Roxb. Afr J Pharm Pharmacol 6(15):1142-1146

11. Bhandari S (2003) Tissue culture studies on Roylea elegans Wall and Zanthoxylum alatum Roxb. Ph.D. thesis, HNB Garhwal University, Uttarakhand

12. Bhatia H, Sharma YP, Manhas RK, Kumar K (2015) Traditional phytoremedies for the treatment of menstrual disorders in district Udhampur, J\&K, India. J Ethnopharmacol 160:202-210

13. Bhumi G, Savithramma N (2014) Biological synthesis of zinc oxide nanoparticles from Catharanthus roseus (L.) G. Don. Leaf extract and validation for antibacterial activity. Int J Drug Dev Res. 6(1):208-214

14. Bisht SS (2003) In vitro organogenesis studies of Centella asiatica (L.) and Swertia angustifolia Buch-Ham, Ph.D. thesis, HNB Garhwal University, Uttarakhand

15. Brayner R, Ferrari-Iliou R, Brivois N, Djediat S, Benedetti MF, Fiévet $F$ (2006) Toxicological impact studies based on Escherichia coli bacteria in ultrafine $\mathrm{ZnO}$ nanoparticles colloidal medium. Nano Lett 6(4):866-870

16. Chakraborty A, Bhattacharya D, Ghanta $S$, Chattopadhyay $S$ (2010) An efficient protocol for in vitro regeneration of Podophyllum hexandrum, a critically endangered medicinal plant. Indian J Biotechnol 9(2):217-220

17. Chithrani BD, Ghazani AA, Chan WCW (2006) Determining the size and shape dependence of gold nanoparticle uptake into mammalian cells. Nano Lett 6:662-668

18. Cullity BD, Stock SR (2001) Elements of X-ray diffraction, 3rd edn. Prenrice Hall, New Jersey

19. Devi RS, Gayathri R (2014) Green synthesis of zinc oxide nanoparticles by using Hibiscus rosa-sinensis. Int J Curr Eng Technol 4(4):2444-2446

20. Dhar U (2002) Conservation implications of plant endemism in high-altitude Himalaya. Curr Sci 82(2):141-148

21. Dhillon GS, Brar SK, Kaur S, Verma M (2012) Green approach for nanoparticle biosynthesis by fungi: current trends and applications. Crit Rev Biotechnol 32:49-73

22. Fakhari S, Jamzad M, Kabiri Fard H (2019) Green synthesis of zinc oxide nanoparticles: a comparison. Green Chem Lett Rev 12(1):19-24

23. Hamayun M, Khan SA, Kim HY, Chae IN, Lee IJ (2006) Traditional knowledge and ex situ conservation of some threatened medicinal plants of Swat Kohistan, Pakistan. Int J Bot 2(2):205-209

24. Huang Z, Zheng X, Yan D, Yin G, Liao X, Kang Y, Hao B (2008) Toxicological effect of $\mathrm{ZnO}$ nanoparticles based on bacteria. Langmuir 24(8):4140-4144

25. Iravani N, Solouki M, Omidi M, Zare AR, Shahnazi S (2010) Callus induction and plant regeneration in Dorem ammoniacum D., an endangered medicinal plant. Plant Cell Organ Cult 100:293-299

26. Jafarirad S, Mehrabi M, Divband B, Kosari-Nasab M (2016) Biofabrication of zinc oxide nanoparticles using fruit extract of Rosa canina and their toxic potential against bacteria: a mechanistic approach. Mater Sci Eng, C 59:296-302

27. Jalal R, Goharshadi EK, Abareshi M, Moosavi M, Yousefi A, Nancarrow P (2010) ZnO nanofluids: green synthesis, characterization, and antibacterial activity. Mater Chem Phys 121(1-2):198-201 
28. Jemal K, Sandeep BV, Pola S (2017) Synthesis, characterization, and evaluation of the antibacterial activity of Allophylus serratus leaf and leaf derived callus extracts mediated silver nanoparticles. J Nanomater. https://doi.org/10.1155/2017/4213275

29. Kala CP, Dhyani PP, Sajwan BS (2006) Developing the medicinal plants sector in northern India: challenges and opportunities. J Ethnobiol Ethnomed 2(1):1-15

30. Kaushik N, Thakkar MS, Snehit S, Mhatre MS, Rasesh Y, Parikh MS (2010) Biological synthesis of metallic nanoparticles. Nanomed Nanotechnol Biol Med 6:257-262

31. Khajuria AK, Bisht NS, Krishan R (2017) Effect of 2,4-D and cytokinins on callus induction in different explants of Viola canescens Wall. ex, Roxb. Plant Arch 17(2):833-838

32. Khajuria AK, Bisht NS, Kumar G (2017) Synthesis of Zinc oxide nanoparticles using leaf extract of Viola canescens Wall. ex, Roxb. and their antimicrobial activity. J Pharmacogn Phytochem 6(5):1301-1304

33. Khajuria AK, Negi A, Bisht NS, Mayura V, Kandwal A (2019) Green synthesis, characterization and antimicrobial activity of synthesized zinc oxide nanoparticles using root extract of Viola canescens Wall. ex. Roxb. Asian J Chem 31(3):551-554

34. Khan MA, Ahmad W, Ahmad M, Nisar M (2017) Hepatoprotective effect of the solvent extracts of Viola canescens Wall. ex. Roxb. against $\mathrm{CCl} 4$ induced toxicity through antioxidant and membrane stabilizing activity. BMC Complement Altern Med 17(1):1-11

35. Laue M (1912) Die Wellentheorie der Röntgenstrahlen. Inaugural lecture, Zürich, 14 December 1912. In Max von Laue. Gesammelte Schriften und Vorträge (1961). Band 1. Vieweg, Braunschweig, pp. 219-244

36. Lee HJ, Lee G, Jang NR, Yun JH, Song JY, Kim BS (2011) Biological synthesis of copper nanoparticles using plant extract. Nanotechnology 1:371-374

37. Lipovsky A, Nitzan Y, Gedanken A, Lubart R (2011) Antifungal activity of $\mathrm{ZnO}$ nanoparticles-the role of ROS mediated cell injury. Nanotechnology 22(10):105101

38. Malik SI, Rashid H, Yasmin T, Minhas M (2004) Callus induction from mature wheat (Triticum aestivum L.) seeds. Int J Agric Biol 6(1):156-159

39. Mann N, Khajuria A, Uniyal PL, Lakhanpaul S (2016) Viola canescens: a potent medicinal herb of Himalaya. Botan 66:58-62

40. Marshall AT, Haverkamp RG, Davies CE, Parsons JG, Gardea-Torresdey JL, van Agterveld D (2007) Accumulation of gold nanoparticles in Brassica juncea. Int J Phytoremediation 9:197-206

41. Meyers MA, Mishra A, Benson DJ (2006) Mechanical properties of nanocrystallinematerials. Prog Mater Sci 51(4):427-556

42. Mittal AK, Chisti Y, Banerjee UC (2013) Synthesis of metallic nanoparticles using plant extracts. Biotechnol Adv 31:346-356

43. Mohammad A, Alam P, Ahmad MM, Ali A, Ahmad J, Abdin MZ (2014) Impact of plant growth regulators (PGRs) on callogenesis and artemisinin content in Artemisia annua L. plants. Indian J Biotechnol 13(1):26-33

44. Molina- Mederos S (2004) In vitro callus induction and plants from stem and petiole explants of Salvia canariensis L. Plant Tissue Cult 14(2):167-172

45. Mukherjee P, Ahmad A, Mandal D, Senapati S, Sainkar SR, Khan MI, Sastry M (2001) Fungus-mediated synthesis of silver nanoparticles and their immobilization in the mycelial matrix: a novel biological approach to nanoparticle synthesis. Nano Lett 1(10):515-519

46. Naqvi QU, Kanwal A, Qaseem S, Naeem M, Ali SR, Shaffique M, Maqbool M (2019) Size-dependent inhibition of bacterial growth by chemically engineered spherical ZnO nanoparticles. J Biol Phy. https://doi.org/10.1007/s10867-019-9520-4
47. Philip D (2011) Mangifera indica leaf-assisted biosynthesis of well-dispersed silver nanoparticles. Spectrochim Acta Part A Mol Biomol Spectrosc 78(1):327-331

48. Phondani PC, Maikhuri RK, Saxena FG (2014) The efficacy of herbal system of medicine in the context of allopathic system in Indian Central Himalaya. J Herbal Med 4(3):147-158

49. Prasad D (2014) Antimicrobial activities of whole plant of Voila canescens and Bauhinia variegate. Biosci Biotechnol Res Asia 11(1):357-358

50. Rana CS, Sharma A, Kumar N, Dangwal LR, Tiwari JK (2010) Ethnopharmacology of some important medicinal plants of Nanda Devi National Park (NDNP) Uttarakhand, India. Nat Sci 8(11):9-14

51. Rana PK, Kumar P, Singhal VK, Rana C (2014) Uses of local plant biodiversity among the Tribal community of Pangi Valley of district Chamba in Cold Desert Himalaya, India. Sci World J. https ://doi.org/10.1155/2014/753289

52. Rao PK, Hasan SS, Bhellum BL, Manhas RK (2015) Ethnomedicinal plants of Kathua district, J\&K, India. J Ethnopharmacol 171:12-27

53. Rawal P, Adhikari RS, Tiwari A (2015) Antifungal activity of Viola canescens against Fusarium oxysporum f. sp. Lycopersici. Int J Curr Microbiol App Sci 4(5):1025-1032

54. Rawat VS (2016) Medicinal plants and sustainable livelihood in Pauri district of Garhwal Himalaya, Uttarakhand, India. Int J Bioassays 5(06):4589-4592

55. Razzaq A, Hadi F, Rashid A, Ibrar M, Ali U (2015) Exploration of medicinal plants and their conservation status at Higher altitude of district Shangla, Khyber Pakhtunkhwa, Pakistan. Am Eurasian J Agric Enivron Sci 15(3):328-331

56. Salam AH, Sivaraj R, Venckatesh R (2014) Green synthesis and characterization of zinc oxide nanoparticles from Ocimum basilicum L. var. purpurascens Benth.-Lamiaceae leaf extract. Mater Lett 131:16-18. https://doi.org/10.1016/j.matlet.2014.05.033

57. Samant SS, Dhar U, Palni LMS (1998) Medicinal plants of Indian Himalaya. Gyanodaya Prakashan, Allahabad

58. Sangeetha G, Rajeshwari S, Venckatesh R (2011) Green synthesis of zinc oxide nanoparticles by Aloe barbadensis miller leaf extract: structure and optical properties. Mater Res Bull 46(12):2560-2566

59. Sawai J, Shoji S, Igarashi H, Hashimoto A, Kokugan T, Shimizu M, Kojima $\mathrm{H}$ (1998) Hydrogen peroxide as an antibacterial factor in zinc oxide powder slurry. J Ferment Bioeng 86(5):521-522

60. Saxena C, Palai SK, Samantaray S, Rout GR, Das P (1997) Plant regeneration from callus cultures of Psoralea corylifolia Linn. Plant Growth Regul 22(1):13-17

61. Schaffer B, Hohenester U, Trugler A, Hofer F (2009) High-resolution surface plasmon imaging of gold nanoparticles by energyfiltered transmission electron microscopy. Phys Rev B 79:041401

62. Senthilkumar SR, Sivakumar T (2014) Green tea (Camellia sinensis) mediated synthesis of zinc oxide $(\mathrm{ZnO})$ nanoparticles and studies on their antimicrobial activities. Int J Pharm Pharm Sci 6(6):461-465

63. Shankar SS, Ahmad A, Sastry M (2003) Geranium leaf assisted biosynthesis of silver nanoparticles. Biotechnol Prog 19(6):1627-1631

64. Sharma D, Sabela MI, Kanchi S, Mdluli PS, Singh G, Stenström TA, Bisetty K (2016) Biosynthesis of ZnO nanoparticles using Jacaranda mimosifolia flowers extract: synergistic antibacterial activity and molecular simulated facet specific adsorption studies. J Photochem Photobiol, B 162:199-207

65. Sharma D, Sabela MI, Kanchi S, Bisetty K, Skelton AA, Honarpar$\operatorname{var} B(2018)$ Green synthesis, characterization and electrochemical sensing of silymarin by $\mathrm{ZnO}$ nanoparticles: experimental and DFT studies. J Electroanal Chem 808:160-172 
66. Sheeba E, Palanivel S, Parvathi S (2013) Effect of plant growth regulators on callus induction in Physalis minima Linn. Int J Innov Res 2(9):4847-4851

67. Singh DK, Hajra PK (1996) Floristic diversity. Chang Perspect Biodivers Status Himal 23:38

68. Singhal G, Riju B, Ashish RS, Rajendra PS (2012) Ecofriendly biosynthesis of gold nanoparticles using medicinally important Ocimum basilicum leaf extract. Adv Sci Eng Med 4:62-66

69. Sirelkhatim A, Mahmud S, Seeni A, Kaus NHM, Ann LC, Bakhori SKM, Mohamad D (2015) Review on zinc oxide nanoparticles: antibacterial activity and toxicity mechanism. Nano-Micro Lett 7(3):219-242

70. Song JY, Jang HK, Kim BS (2009) Biological synthesis of gold nanoparticles using Magnolia kobus and Diospyros kaki leaf extracts. Process Biochem 44:1133-1138

71. Sun S, Murray C, Weller D, Folks L, Moser A (2000) Monodisperse FePt nanoparticles and ferromagnetic FePt nanocrystal superlattices. Science 287:1989-1992

72. Surekha K, Abirami R, Prasidhee V, Jacob S (2018) Green synthesis of zinc oxide nanoparticle using Pentatropis capensis and its anti-proliferative activity. Indian J Nat Prod Resour 8(4):316-321

73. Van Dijken A, Meulenkamp EA, Vanmaekelbergh D, Meijerink A (2000) Identification of the transition responsible for the visible emission in $\mathrm{ZnO}$ using quantum size effects. J Lumin 90(3-4):123-128
74. Vanaja M, Annadurai G (2013) Coleus aromaticus leaf extract mediated synthesis of silver nanoparticles and its bactericidal activity. Appl Nanosci 3(3):217-223

75. Verma G, Dua VK, Agarwal DD, Atul PK (2011) Antimalarial activity of Holarrhena antidysenterica and Viola canescens, plants traditionally used against malaria in the Garhwal region of northwest Himalaya. Malar J 10(20):2-5

76. Xia T, Kovochich M, Liong M, Mädler L, Gilbert B, Shi H, Nel AE (2008) Comparison of the mechanism of toxicity of zinc oxide and cerium oxide nanoparticles based on dissolution and oxidative stress properties. ACS Nano 2(10):2121-2134

77. Zhang L, Jiang Y, Ding Y, Povey M, York D (2007) Investigation into the antibacterial behaviour of suspensions of $\mathrm{ZnO}$ nanoparticles (ZnO nanofluids). J Nanopart Res 9(3):479-489

78. Zhang L, Ding Y, Povey M, York D (2008) ZnO nanofluids-a potential antibacterial agent. Prog Nat Sci 18(8):939-944

79. Zhang H, Lv X, Li Y, Wang Y, Li J (2009) P25-graphene composite as a high performance photocatalyst. ACS Nano 4(1):380-386

Publisher's Note Springer Nature remains neutral with regard to jurisdictional claims in published maps and institutional affiliations. 